\title{
Expression of epidermal growth factor receptor in neoplastic pituitary cells: evidence for a role in corticotropinoma cells
}

\author{
M Theodoropoulou, T Arzberger ${ }^{1}$, Y Gruebler, M L Jaffrain-Rea ${ }^{2}$, \\ J Schlegel ${ }^{3}$, L Schaaf, E Petrangeli ${ }^{2}$, M Losa ${ }^{4}$, G K Stalla and \\ U Pagotto ${ }^{5}$
}

\author{
Neuroendocrinology Group, Max Planck Institute of Psychiatry, 80804 Munich, Germany \\ ${ }^{1}$ Institute of Pathology, Division of Neuropathology, University of Wurzburg, Germany \\ ${ }^{2}$ Department of Experimental Medicine, University of L'Aquila, 67100 L'Aquila, Italy CNR, Rome, Italy \\ ${ }^{3}$ Division of Neuropathology, Institute of Pathology, Munich Technical University, 81675 Munich, Germany \\ ${ }^{4}$ Neurosurgical Department, Hospital San Raffaele 20132 Milan, Italy \\ ${ }^{5}$ Endocrine Unit, Department of Internal Medicine and Gastroenterology and Center for Applied Biomedical Research (C.R.B.A.), \\ S. Orsola-Malpighi General Hospital, 40125 Bologna, Italy \\ (Requests for offprints should be addressed to M Theodoropoulou; Email: marily@mpipsykl.mpg.de)
}

\begin{abstract}
The oncogenic effects of epidermal growth factor (EGF) have long been established. EGF receptor (EGFr) is overexpressed in many types of tumors and constitutes a target for cancer treatment. The pituitary gland is a target of EGF action and it is very likely that EGFr plays a role in pituitary tumor formation and progression. However, there is a controversy in the literature concerning EGFr expression in the different types of pituitary adenomas. In the present study we investigated the expression pattern of the wild type EGFr (EGFrWT) and the constitutively active variant III (EGFrvIII) at the mRNA and protein levels in a large series of pituitary tumors. EGFrWT was found in a high percentage of hormone-secreting tumors, but only in a small fraction of non-functioning pituitary adenomas, while no expression of the EGFrvIII could be detected by nested RT-PCR in any tumor. Among the hormone-secreting adenomas, the highest incidence
\end{abstract}

of EGFr expression was found in Cushing's pituitary adenomas. Furthermore, immunohistochemistry for the phosphorylated EGFr revealed the presence of activated EGFr in most Cushing's adenomas, compared with most pituitary adenomas. Taking into account that downregulation of p27/Kip1 plays a significant role in corticotrope tumorigenesis and that EGFr mitogenic signaling results in decreased p27/Kip1, we searched for a correlation between EGFr expression and p27/Kip1 levels in corticotropinomas. Low p27/Kip1 immunoreactivity was observed in corticotropinomas expressing EGFr. On the other hand, somatotropinomas expressing EGFr had high p27/Kip1 immunoreactivity. These data suggest a corticotrope-specific phenomenon and indicate that EGFr may have a role in the unbalanced growth of corticotrope tumoral cells.

Journal of Endocrinology (2004) 183, 385-394

\section{Introduction}

Pituitary adenomas are benign tumors which account for $15 \%$ of all intracranial neoplasms. Despite the extensive studies performed to elucidate the molecular defects present in pituitary adenomas, their pathogenesis is still obscure (Asa \& Ezzat 1998). Alterations in the expression of tumor suppressor genes, such as p16/INK4 and $p 27 /$ Kip1, have been described in non-functioning pituitary adenomas (NFPA) and corticotropinomas (CUSH) respectively (Jaffrain-Rea et al. 1999, Lidhar et al. 1999, Simpson et al. 1999), and we have recently shown that the expression of the putative tumor suppressor gene $Z A C$ is decreased in all types of pituitary adenomas and is dramatically reduced or lost in NFPA (Pagotto et al. 2000). However, apart from alterations in the expression of genes controlling the cell cycle, it is well known that tumorigenesis and tumor progression can be triggered by the uncontrolled mitogenic action of growth factors. The pituitary gland has been shown to be a rich source of growth factors, which act in an autocrine/paracrine fashion to regulate pituitary hormone secretion and cell proliferation (Renner et al. 1996, Ray \& Melmed 1997).

One of the growth factors most frequently involved in cancer is epidermal growth factor (EGF). EGF exerts its effects upon binding to a tyrosine kinase receptor, which is the cellular homolog of the $v$-erbB oncogene product (Downward et al. 1984). EGF receptor (EGFr) is often 
found to be overexpressed in a wide range of tumors, such as breast and ovarian cancer and glial cell tumors (Xu et al. 1984, Klijn et al. 1992). In addition, the constitutively active variant of the EGFr, EGFrvIII, which derives from an $801 \mathrm{bp}$ in-frame deletion in the extracellular part of the receptor, is often present in several forms of cancer (Sugawa et al. 1990, Tang et al. 2000). Furthermore, phosphorylation of EGFr tyrosine kinase was found to associate with pure prognosis of non-small cell lung cancer patients (Kanematsu et al. 2003).

In the pituitary gland, EGF is an important regulator of hormone secretion and cell proliferation (White \& Bancroft 1983, Childs et al. 1995). Despite the fact that there is clear evidence of the presence of EGFr in the normal adenohypophysis (Chabot et al. 1986, Fan \& Childs 1995), the data concerning the expression of EGFr in pituitary tumors are still controversial (Ray \& Melmed 1997, Dahia \& Grossman 1999). Initial studies had failed to show any EGF binding sites in human pituitary adenomas (Birman et al. 1987), while further investigations using immunohistochemical and RT-PCR approaches have described EGFr in pituitary adenomas, with one study demonstrating overexpression in most non-functional pituitary adenomas but absence in the hormone-secreting types (Chaidarun et al. 1994), and another showing EGFr expression in all types of pituitary adenomas but at varying levels (LeRiche et al. 1996). In the latter study, a positive correlation between EGFr expression and tumor aggressiveness was found. Accordingly, a recent report revealed a broad distribution of EGF-binding sites in human pituitary macroadenomas, especially in macro-prolactinomas, also suggesting a link with tumor invasiveness (Jaffrain-Rea et al. 1998).

In the present study, we investigated the expression of EGFr mRNA and protein and, for the first time, of EGFrvIII mRNA, in the normal human pituitary and in a broad range of different types of pituitary adenomas, combining results derived from RT-PCR, immunohistochemistry (IHC) and competitive binding assays. In addition, we examined the presence of the phosphorylated EGFr.

\section{Materials and Methods}

Tissues

This study was approved by the ethics committee of the Max Planck Institute and informed consent was received from each patient or from their relatives. Samples from five human pituitary glands were obtained from autopsy cases without any evidence of endocrinological disease, with a post mortem delay of between 8 and $12 \mathrm{~h}$. A number of 102 pituitary tumors (19 acromegaly-associated (ACRO), 13 prolactinomas (PROL), 16 CUSH, 5 thyreotropinomas (TSH-oma) and 49 NFPA) were obtained after operation, snap-frozen, and stored at $-80^{\circ} \mathrm{C}$. From these samples,
72 cases were also available as paraffin-embedded sections (15 ACRO, 9 PROL, 5 CUSH, 3 TSH-oma, 40 NFPA). Forty-seven of one hundred and two adenomas (9 ACRO, 4 PROL, 2 CUSH, 2 TSH-oma, and 30 NFPA) provided enough tissue for additional RNA extraction. Adenomas were diagnosed by clinical, radiological and surgical findings. All tumors were benign and graded according to a modified Hardy's classification (Boggild et al. 1994).

Five human meningiomas (2 frozen and 3 paraffinembedded) and five glioblastomas (all paraffin-embedded) were used as positive controls for EGFr mRNA expression and for IHC.

\section{$R N A$ extraction and $R T-P C R$}

RNA was extracted from 3 human anterior pituitaries, 47 pituitary adenomas and 1 anaplastic meningioma already known to express EGFr. One microgram RNA was reversely transcribed as previously described (Pagotto et al. 1995). Two microliters of the transcription reaction were amplified by nested PCR for EGFr and EGFrvIII as previously described (Schlegel et al. 1994). In brief, PCR was performed using NP1/2 as the outer primer pair, and NP6/7 or JS3/4 as the inner primer pair. NP6/7 amplifies a 1002 bp PCR fragment in the case of wild-type EGFr (EGFrWT), or a $201 \mathrm{bp}$ fragment remaining from the deletion of the coding region of exon 2 through exon 7 that characterizes EGFrvIII. Control PCR using JS3/4 revealed a 391 bp band corresponding to EGFrWT, which is expected in all samples expressing EGFr or EGFrvIII. Fifteen microliters of the reaction products were separated on a $1 \cdot 2 \%$ agarose gel and visualized by staining with ethidium bromide. A plasmid containing an EGFrvIII fragment (201 bp) recognized by the NP6/7, a plasmid containing the $391 \mathrm{bp}$ of the EGFr recognized by the $\mathrm{JS} 3 / 4$, and reversely transcribed RNA from the anaplastic meningioma known to express high levels of EGFr mRNA, were amplified as positive controls (Schlegel et al. 1994).

The integrity of the RNA from each sample was confirmed by PCR $\left(94^{\circ} \mathrm{C}\right.$ for $1 \mathrm{~min}, 60^{\circ} \mathrm{C}$ for $1 \mathrm{~min}$, $72{ }^{\circ} \mathrm{C}$ for $1 \mathrm{~min}$; 35 cycles) for human $\beta$-actin (sense primer: 5'-CTAGAAGCATTGCGGTGGACGATG-3', and antisense primer: $5^{\prime}$ - ACGGGGTCACCCACACTG TGC-3'; fragment size $660 \mathrm{bp}$ ).

\section{Immunohistochemistry (IHC)}

To assess the EGFr protein status, two different antibodies (ab) were used: a mouse monoclonal antibody against the intracellular domain of the human EGFr (residues 985996; clone F4; Sigma, St Louis, MO, USA), and a mouse monoclonal antibody against the extracellular domain of the receptor (clone E30; Biogenex, San Ramon, CA, USA). The first was applicable on both frozen and paraffin-embedded tissues, while the latter was applicable 
only on paraffin-embedded tissue. To determine the presence of the activated EGFr, the rabbit polyclonal phospho (Tyr992)-EGFr and phospho (Tyr1068)-EGFr antibodies (Cell Signaling Technology Inc., Beverly, MA, USA) were used at 1:100 dilution, only on paraffin sections.

Mouse monoclonal antibodies were used to assess the expression of pituitary hormones, and were diluted as follows: anti-follicle-stimulating hormone 1:800, antiluteinizing hormone 1:800, anti-thyrotropin (TSH) 1:800, anti-prolactin 1:400, and anti- $\alpha$-subunit 1:500 (Immunotech, Karlsruhe, Germany); anti-adrenocorticotropin (ACTH) 1:100 (Dako Diagnostika, Hamburg, Germany) and anti-growth hormone (GH) 1:800 (a generous gift from Dr C J Strasburger, Dept. of Medicine, University of Munich, Germany). Rabbit antiserum against the folliculostellate cell marker S100 (Biogenesis, Poole, Dorset, UK) was diluted 1:20. The rabbit polyclonal anti-p27/Kip1 antibody (Santa Cruz Biotechnology, Santa Cruz, CA, USA; 1:500), was used to examine the p27 protein levels in some pituitary adenoma cases.

Sections $(8 \mu \mathrm{m})$ were cut in a cryostat, fixed in freshly prepared $4 \%$ paraformaldehyde for $5 \mathrm{~min}$, and stored in 96\% ethanol. IHC was performed as follows: after blocking the endogenous peroxidase activity in $0.3 \%$ hydrogen peroxide in Tris-buffered saline (TBS) for $15 \mathrm{~min}$, sections were immersed in horse serum diluted 1:10 in TBS for 30 min to reduce nonspecific binding, and incubated with the primary antibody overnight at $4{ }^{\circ} \mathrm{C}$. After washing in TBS, sections were incubated in biotinylated horse antimouse or goat anti-rabbit IgG (Vector, Burlingame, CA, USA; 1:300 dilution) for $30 \mathrm{~min}$ and in avidin-biotinperoxidase complex (Vectastain Elite Kit, Vector) for $30 \mathrm{~min}$. Immunoreactivity was visualized using $1 \mathrm{mg} / \mathrm{ml}$ diaminobenzidine (DAB) as chromogen and $0.01 \%$ hydrogen peroxide as substrate. After each step of the staining procedure, the sections were washed three times in TBS for $5 \mathrm{~min}$ each. Peroxidase reaction was stopped after $5 \mathrm{~min}$ in distilled water, and sections were counterstained in Toluidine Blue, dehydrated and mounted with Entellan.

Paraffin sections were deparaffinized in xylol, gradually rehydrated and then processed as described above. Paraffin sections stained for EGFr with the Biogenex clone E30 ab and for phospho-EGFr were pretreated with pepsin and $10 \mathrm{mM}$ citrate respectively, according to the manufacturer's instructions.

Double IHC for the EGFr and hormone colocalization was carried out by performing, first, IHC for the EGFr, visualizing immunoreactivity with $\mathrm{DAB}$, and then IHC for the hormone, visualizing immunoreactivity with Vector Red (Vector), as previously described (Pagotto et al. 2000). All the buffers used were phosphate-free. Endogenous alkaline phosphatase activity was blocked by adding $10 \mathrm{mmol} / \mathrm{l}$ levamisole (Sigma) to the Vector Red substrate.
IHC staining for each tumor was judged by two independent investigators.

\section{EGF binding experiments}

Eleven adenomas (2 ACRO, 2 PROL, 7 NFPA; kindly provided by Dr Di Stefano, Rome) were used to compare IHC and EGF-binding as previously described (Jaffrain-Rea et al. 1998). In brief, frozen samples were homogenized and the membrane pellet obtained by ultracentrifugation was treated with $\mathrm{MgCl}_{2}$; binding experiments were carried out in triplicate using a single $1 \mathrm{nM}$ concentration of ${ }^{125}$ I-EGF (specific activity 150-200 $\mathrm{mCi} / \mathrm{mg}$, New England Nuclear, Dupont de Nemours, France), which merely correlates with the capacity for high affinity EGF-binding sites in Scatchard analysis (Jaffrain-Rea et al. 1998). Positive controls were represented by samples from benign prostatic hyperplasia and breast cancer, with known EGFr binding (range: 5-75 and 50-2000 fmol/mg protein respectively) (Lubrano et al. 1993, Petrangeli et al. 1995).

\section{Statistics}

The percentage of cells immunopositive for EGFr was compared between each tumor category using the Dunn's test. $P$ values less than 0.05 were considered to be significant.

\section{Results}

EGFr mRNA expression in normal and adenomatous human pituitary

$\mathrm{RT} /$ nested PCR in all three normal pituitary glands resulted in an amplification of the predicted $1002 \mathrm{bp}$ band corresponding to the EGFrWT. One meningioma was used as a positive control. EGFr mRNA expression was examined in 47 out of 102 pituitary adenomas, which provided enough tissue for RNA extraction (Table 1). EGFr transcripts were found in the $2 \mathrm{CUSH}, 6$ of 9 ACRO, 1 of 4 PROL, and 19 of 30 NFPA, while the 2 TSH-omas had no detectable EGFr mRNA. The constitutively active EGFrvIII was not detected in any of the 47 tumors studied (Fig. 1A). Authenticity of amplification products was verified by probing with EGFr cDNA fragments (data not shown; Pagotto et al. 2000).

\section{EGFr protein in normal and adenomatous human pituitary}

To assess the EGFr protein status, two monoclonal antibodies were used, one against the intracellular (clone F4), and the other against the extracellular (clone E30) part of the receptor. Both antibodies were tested on five EGFr-immunopositive glioblastoma and five meningioma 
Table 1 Data dervied from RT-PCR and immunohistochemistry in 102 pituitary adenomas which included 19 acromegaly-associated tumors (ACRO), 13 prolactinomas (PROL), 16 corticotropinomas (CUSH), 5 thyreotropinomas (TSH) and 49 non-functioning pituitary adenomas (NFPA)

\begin{tabular}{|c|c|c|c|c|}
\hline \multirow[b]{2}{*}{ No. } & \multirow[t]{2}{*}{ Type } & \multirow[t]{2}{*}{$\begin{array}{l}\text { EGFr } \\
\text { mRNA* }\end{array}$} & \multirow[t]{2}{*}{$\begin{array}{l}\% \text { EGFr } \\
\text { ip cells } †\end{array}$} & \multirow[t]{2}{*}{$\begin{array}{l}\% \text { EGFr-P } \\
\text { ip cells† }\end{array}$} \\
\hline & & & & \\
\hline 1. & ACRO & - & 0 & 0 \\
\hline 2. & ACRO & + & 30 & 5 \\
\hline 3. & ACRO & + & 10 & 1 \\
\hline 4. & ACRO & + & 0 & 0 \\
\hline 5. & ACRO & + & 0 & n.d. \\
\hline 6. & ACRO & + & 5 & 0 \\
\hline 7. & ACRO & + & 2 & n.d. \\
\hline 8. & ACRO & - & 0 & 0 \\
\hline 9. & ACRO & - & 0 & 0 \\
\hline 10. & ACRO & n.d. & 0 & 0 \\
\hline 11. & ACRO & n.d. & 0 & n.d. \\
\hline 12. & ACRO & n.d. & 5 & 0 \\
\hline 13. & ACRO & n.d. & 0 & n.d. \\
\hline 14. & ACRO & n.d. & 2 & 0 \\
\hline 15. & ACRO & n.d. & 5 & n.d. \\
\hline 16. & ACRO & n.d. & 0 & n.d. \\
\hline 17. & ACRO & n.d. & 0 & 0 \\
\hline 18. & ACRO & n.d. & 10 & n.d. \\
\hline 19. & ACRO & n.d. & 0 & n.d. \\
\hline 20. & PROL & - & 0 & n.d. \\
\hline 21. & PROL & - & 0 & n.d. \\
\hline 22. & PROL & - & 0 & n.d. \\
\hline 23. & PROL & + & 1 & n.d. \\
\hline 24. & PROL & n.d. & 0 & n.d. \\
\hline 25. & PROL & n.d. & 1 & n.d. \\
\hline 26. & PROL & n.d. & 0 & n.d. \\
\hline 27. & PROL & n.d. & 2 & n.d. \\
\hline 28. & PROL & n.d. & 30 & n.d. \\
\hline 29. & PROL & n.d. & 1 & n.d. \\
\hline 30. & PROL & n.d. & 2 & n.d. \\
\hline 31. & PROL & n.d. & 0 & n.d. \\
\hline 32. & PROL & n.d. & 0 & n.d. \\
\hline 33. & CUSH & + & 50 & n.d. \\
\hline 34. & CUSH & + & 40 & 40 \\
\hline 35. & $\mathrm{CUSH}$ & n.d. & 0 & 0 \\
\hline 36. & CUSH & n.d. & 10 & 5 \\
\hline 37. & CUSH & n.d. & 40 & n.d. \\
\hline 38. & CUSH & n.d. & 0 & n.d. \\
\hline 39. & CUSH & n.d. & 50 & 50 \\
\hline 40. & CUSH & n.d. & 0 & n.d. \\
\hline 41. & $\mathrm{CUSH}$ & n.d. & 10 & 2 \\
\hline 42. & CUSH & n.d. & 0 & n.d. \\
\hline 43. & $\mathrm{CUSH}$ & n.d. & 10 & n.d. \\
\hline 44. & CUSH & n.d. & 50 & n.d. \\
\hline 45. & $\mathrm{CUSH}$ & n.d. & 40 & n.d. \\
\hline 46. & $\mathrm{CUSH}$ & n.d. & 20 & n.d. \\
\hline 47. & CUSH & n.d. & 30 & n.d. \\
\hline 48. & $\mathrm{CUSH}$ & n.d. & 20 & n.d. \\
\hline 49. & TSH & - & 0 & n.d. \\
\hline 50. & TSH & - & 0 & n.d. \\
\hline 51. & TSH & n.d. & 10 & n.d. \\
\hline 52. & TSH & n.d. & 5 & n.d. \\
\hline 53. & TSH & n.d. & 0 & n.d. \\
\hline 54. & NFPA & - & 0 & n.d. \\
\hline 55. & NFPA & - & 0 & 0 \\
\hline 56. & NFPA & + & 0 & 0 \\
\hline
\end{tabular}

Table 1 Continued

\begin{tabular}{|c|c|c|c|c|}
\hline & Type & $\begin{array}{l}\text { EGFr } \\
\text { mRNA* }\end{array}$ & $\begin{array}{l}\% \text { EGFr } \\
\text { ip cells } \dagger\end{array}$ & $\begin{array}{l}\text { \% EGFr-P } \\
\text { ip cells } \dagger\end{array}$ \\
\hline \multicolumn{5}{|l|}{ No. } \\
\hline 57. & NFPA & + & 0 & 0 \\
\hline 58. & NFPA & + & 0 & 0 \\
\hline 59. & NFPA & + & 5 & $<1$ \\
\hline 60. & NFPA & + & 0 & 0 \\
\hline 61. & NFPA & + & 2 & $<1$ \\
\hline 62. & NFPA & + & 0 & 0 \\
\hline 63. & NFPA & + & 2 & n.d. \\
\hline 64. & NFPA & - & 0 & 0 \\
\hline 65. & NFPA & - & 0 & n.d. \\
\hline 66. & NFPA & + & 10 & $<1$ \\
\hline 67. & NFPA & + & 0 & 0 \\
\hline 68. & NFPA & + & 0 & 0 \\
\hline 69. & NFPA & + & 1 & 0 \\
\hline 70. & NFPA & + & 2 & $<1$ \\
\hline 71. & NFPA & + & 0 & 0 \\
\hline 72. & NFPA & + & 0 & n.d. \\
\hline 73. & NFPA & + & 1 & n.d. \\
\hline 74. & NFPA & + & 0 & 0 \\
\hline 75. & NFPA & - & 0 & 0 \\
\hline 76. & NFPA & - & 0 & 0 \\
\hline 77. & NFPA & + & 1 & $<1$ \\
\hline 78. & NFPA & - & 0 & 0 \\
\hline 79. & NFPA & - & 0 & 0 \\
\hline 80. & NFPA & - & 0 & 0 \\
\hline 81. & NFPA & - & 0 & 0 \\
\hline 82. & NFPA & + & 0 & 0 \\
\hline 83. & NFPA & - & 0 & 0 \\
\hline 84. & NFPA & n.d. & 0 & n.d. \\
\hline 85. & NFPA & n.d. & 0 & n.d. \\
\hline 86. & NFPA & n.d. & 0 & 0 \\
\hline 87. & NFPA & n.d. & 0 & n.d. \\
\hline 88. & NFPA & n.d. & 0 & 0 \\
\hline 89. & NFPA & n.d. & 0 & 0 \\
\hline 90. & NFPA & n.d. & 0 & n.d. \\
\hline 91. & NFPA & n.d. & 0 & 0 \\
\hline 92. & NFPA & n.d. & 0 & 0 \\
\hline 93. & NFPA & n.d. & 0 & n.d. \\
\hline 94. & NFPA & n.d. & 0 & n.d. \\
\hline 95. & NFPA & n.d. & 0 & n.d. \\
\hline 96. & NFPA & n.d. & 0 & n.d. \\
\hline 97. & NFPA & n.d. & 0 & n.d. \\
\hline 98. & NFPA & n.d. & 0 & n.d. \\
\hline 99. & NFPA & n.d. & 0 & n.d. \\
\hline 100. & NFPA & n.d. & 0 & n.d. \\
\hline 101. & NFPA & n.d. & 0 & n.d. \\
\hline 102. & NFPA & n.d. & 40 & n.d. \\
\hline
\end{tabular}

*EGFr mRNA: presence $(+)$ or absence $(-)$ of EGFr transcript as verified by nested PCR; $\uparrow \%$ ip cells: percentage of endocrine cells immunopositive (ip) for EGFr and phospho (Tyr992)-EGFr (EGFr-P). n.d.: not determined

tissues (data not shown). The clone E30 ab showed staining mainly of the cell membrane, while clone F4 ab displayed a cytoplasmatic staining. In the case of clone F4 $\mathrm{ab}$, the availability of the homologous antigen enabled us to preabsorb the antibody, confirming its specificity.

In the normal pituitary gland, EGFr immunoreactivity was localized in $10-30 \%$ of the anterior pituitary endocrine 

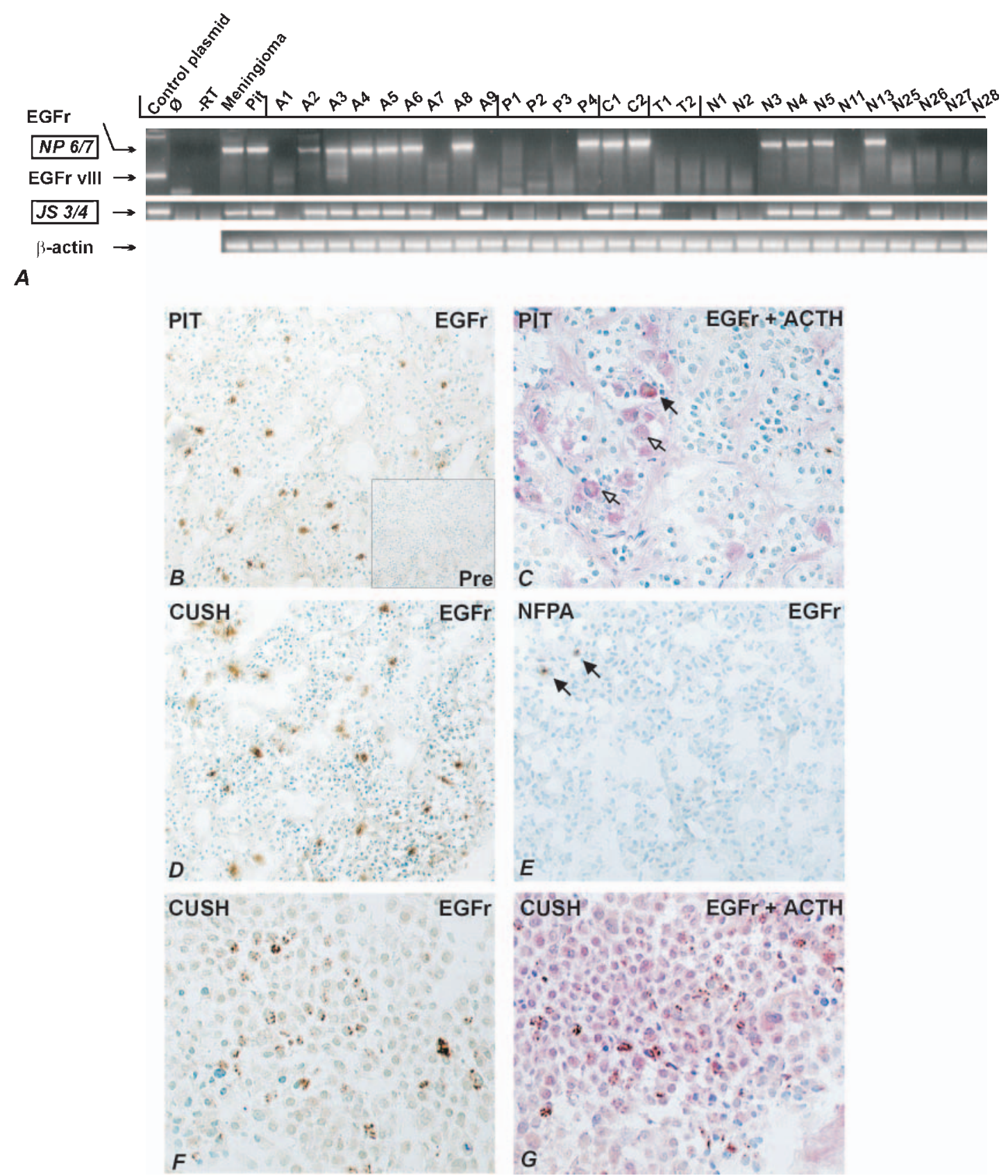

Figure 1 EGFr expression in normal and adenomatous pituitary. (A) Top panel: nested PCR screening for EGFrWT (1002 bp) and EGFr vIII (201 bp) using the NP6/7 inner primer pair. Control plasmid shows the position of the band corresponding to the EGFr vIll; $\varnothing$, PCR in the absence of template; - RT, meningioma RNA without reverse transcriptase; Meningioma, positive control for the EGFrWT; Pit, normal anterior pituitary gland. Middle panel: control PCR using the JS3/4 inner primer pair reveals the presence of EGFr; control plasmid for JS3/4 shows the position of the band corresponding to the EGFr fragment. Bottom panel: $\beta$-actin in the same set of tumors. (B) EGFr protein (brown) in human adenohypophysis using the clone F4 antibody. EGFr immunopositive cells are scattered comprising around 10\% of anterior pituitary endocrine cells. Inset: parallel section incubated with the preabsorbed clone F4 antibody, demonstrating that all the staining is abolished. (C) Double IHC showing EGFr (brown) colocalization with adrenocorticotropin (ACTH) (red) in the normal pituitary. Only a small number of ACTH immunopositive cells express EGFr (solid arrow), while the majority are immunonegative (open arrows). (D) EGFr staining in a representative CUSH (No. 46). About 20\% of cells show EGFr immunoreactivity. (E) Representative EGFr immunopositive NFPA (No. 61). Only a small number of cells have EGFr immunoreactivity (solid arrows). (F) Another CUSH (No. 34) displaying high EGFr immunoreactivity. (G) Double IHC on the same CUSH confirming that EGFr immunoreactivity is in the ACTH-positive cells of the tumor. All the stainings were performed in cryostat sections. Nuclei are counterstained with Toluidine Blue. 
cells (Fig. 1B), and the staining was abolished after preabsorption of the clone F4 ab (Fig. 1B, inset). DoubleIHC revealed EGFr immunoreactivity in somatotropes, corticotropes, lactotropes, and gonadotropes (e.g. colocalization with ACTH in Fig. 1C), which is in accordance with previous observations in rat anterior pituitary cells (Fan \& Childs 1995). In addition, EGFr was found to be expressed in a small percentage of folliculostellate cells, as revealed by the colocalization with the folliculostellate cell marker S100 (data not shown).

EGFr expression was examined using the clone F4 ab in a set of 102 pituitary adenomas in cryostat sections. The clone E30 ab worked only in paraffin-embedded sections, therefore IHC using this antibody was possible in 72 of 102 adenomas which were also available as paraffin-embedded sections.

The 102 pituitary tumors were divided into 53 clinically active adenomas and 49 NFPA. From the 53 clinically active adenomas, 28 were immunopositive for EGFr, while only 8 of 49 NFPA displayed EGFr immunoreactivity. As shown in Table 1, the percentage of endocrine cells immunopositive for the receptor was $2-30 \%( \pm 1 \cdot 651)$ in ACRO, $1-30 \%( \pm 2 \cdot 273)$ in PROL and 5 and $10 \%$ in the two immunopositive TSH-omas, reaching $50 \%(10-50 \% \pm 4.892)$ in most CUSH (e.g. in Fig. 1D and F). The percentage of immunopositive cells in CUSH was significantly higher compared with ACRO or PROL $(P<0 \cdot 005)$. In order to exclude the possibility that the signal observed in these cases of CUSH belongs to normal pituitary cells contaminating the tumor, double IHC was performed and this confirmed that the observed EGFr immunoreactivity is confined to the corticotropes of the tumor (Fig.1G). In the eight NFPA, EGFr immunopositive cells did not exceed the 10\% level $(1-10 \% \pm$ 0.231; e.g. in Fig. 1E). The percentage of immunopositive cells in NFPA was significantly lower compared with ACRO $(P<0 \cdot 05)$ and CUSH $(P<0 \cdot 001)$. The only silent corticotropinoma (No. 102, Table 1) included in the study displayed EGFr expression in $40 \%$ of the cells, similar to the clinically active CUSH.

IHC with the clone E30 ab gave similar results. This part of the study was performed in 72 out of 102 tumors for which we had paraffin-embedded sections, since this antibody works only on paraffin; 12 of 32 clinically active and 3 of 40 NFPA were immunopositive for EGFr using the clone E30 ab. Similar to the results obtained with the clone F4 ab, CUSH was the tumor type with the highest number of immunopositive cases (4 of 5 cases) and the highest percentage of immunopositive cells; 4 of 15 ACRO and 3 of 9 PROL displayed 1-30\% of immunopositive cells, while 1 of 3 TSH-oma had 10\% EGFr expressing cells.

\section{EGF binding in pituitary tumors}

Analysis of 11 pituitary adenomas (2 ACRO, 2 PROL, 7 NFPA) revealed a highly variable distribution of EGF binding sites, ranging from 0 to $332 \mathrm{fmol} / \mathrm{mg}$ protein. EGFr positivity $(\geq 10 \mathrm{fmol} / \mathrm{mg}$ protein) was present in the two ACRO (58.7 and $101.3 \mathrm{fmol} / \mathrm{mg}$ protein) and the two PROL (228 and $233.2 \mathrm{fmol} / \mathrm{mg}$ protein), as well as in two of seven NFPA $(332.0$ and $65.0 \mathrm{fmol} / \mathrm{mg}$ protein).

IHC on the same specimens showed that all the samples negative for EGF binding were also immunonegative for EGFr, while four out of six cases displaying EGF binding had a significant number of EGFr immunopositive endocrine cells. In the other two cases, there were areas with intense EGFr immunoreactivity dispersed throughout the tissue, but the tissue was too fibrotic to identify distinct cells.

\section{Correlation between EGFr and p27/Kip1 immunoreactivity in corticotropinoma cells}

p27 is a well known target of EGFr signaling in many cell models (Schlessinger \& Ullrich 1992). In order to see if there is any correlation between expression of EGFr and downregulation of $\mathrm{p} 27 / \mathrm{Kip} 1$ in pituitary tumors, IHC was performed for EGFr and p27 in parallel sections in some CUSH and ACRO cases (e.g. in Fig. 2). CUSH expressing EGFr had almost no p27 immunoreactivity. On the other hand EGFr expressing ACRO still retained p27/ Kip1 immunoreactivity indicating a corticotrope-specific phenomenon.

\section{Phospho-EGFr protein in normal and adenomatous human pituitary}

In order to determine the presence of the activated EGFr in the normal and adenomatous pituitary, IHC was performed using polyclonal antibodies specific for EGFr phosphorylated at two different tyrosines. IHC with an antibody recognizing the EGFr phosphorylated at tyrosine 922 revealed signal in a small number of cells $(\leq 1 \%)$ in human anterior pituitary, which tended to form small clusters (Fig. 3A). IHC performed on 46 pituitary adenomas (11 ACRO, 5 CUSH and 30 NFPA), revealed immunoreactivity in 2 out of 11 ACRO (1\% and 5\% immunopositive cells; Table 1, Fig. 3B) and in 4 out of 5 CUSH $(2-50 \% \pm 10 \cdot 6$; Table 1, Fig. 3 C and D). On the other hand, 3 out of 11 ACRO which expressed EGFr were not immunopositive for phospho (Tyr992)-EGFr (Nos 6,12 and 14 in Table 1), while all the 4 CUSH with EGFr immunoreactivity also had the phosphorylated form. From the 30 NFPA examined, 5 displayed a small number of phospho (Tyr992)-EGFr immunopositive cells, which was less that $1 \%$. As in the case of normal pituitary, phospho (Tyr992)-EGFr immunopositive cells tended to form clusters or to be present in one defined area of the tumor.

No immunoreactivity was detected in the normal and adenomatous pituitaries when an antibody recognizing the EGFr phosphorylated at tyrosine 1068 was used. 

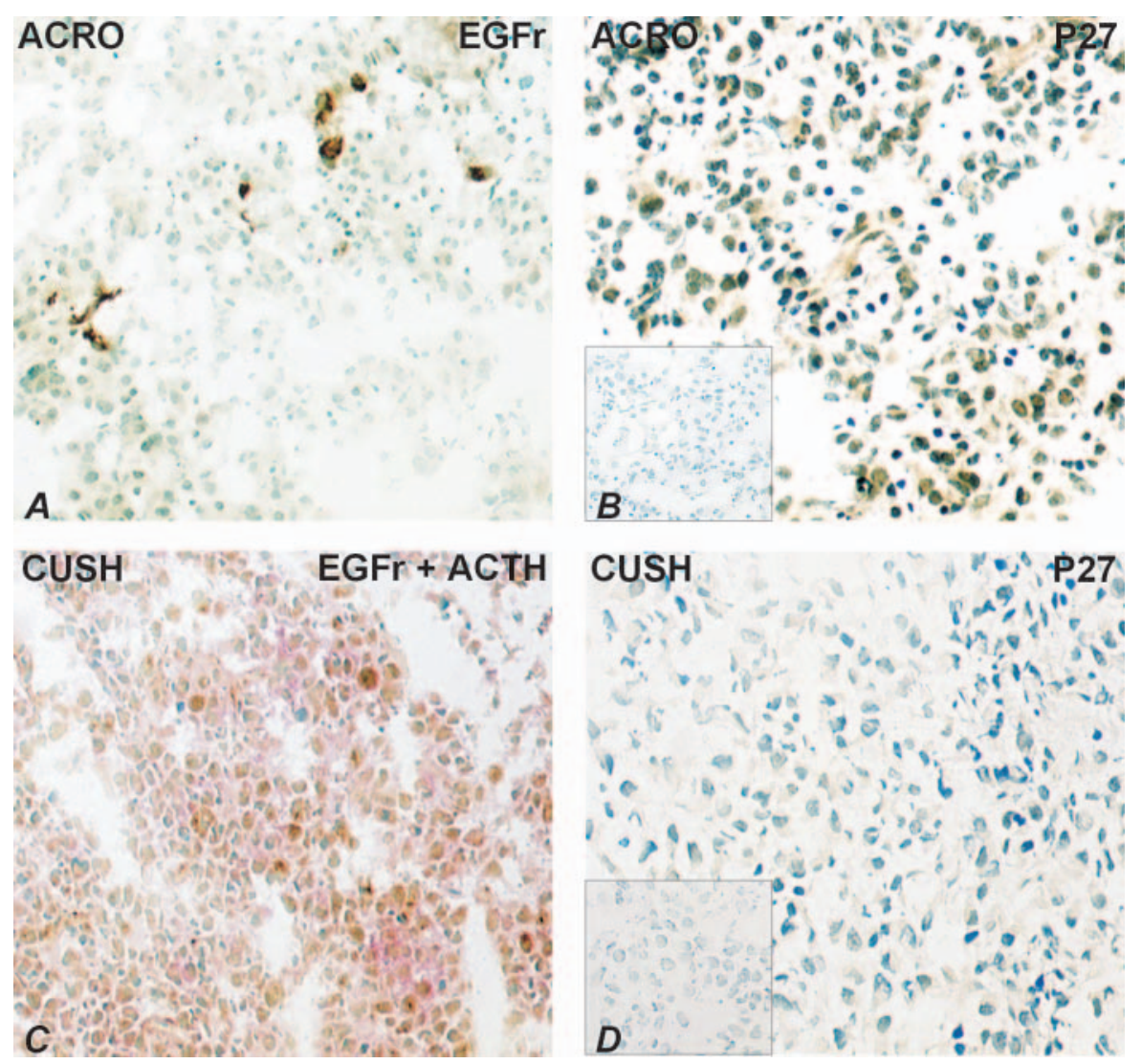

Figure 2 ( $A$ and $C$ ) EGFr expression in an ACRO (No. 2) and a CUSH (No. 33). (B and D) p27/Kip1 immunoreactivity on adjacent slides, ACRO and CUSH respectively, showing p27 expression in the ACRO but not in the CUSH. Insets: parallel sections without the primary antibody. Nuclei are counterstained with Toluidine Blue.

\section{Discussion}

EGFr plays an important role in the progression of many types of cancer by activation of mitogenic pathways and altering cell cycle progression usually by downregulating the expression of tumor suppressor genes.

In this study we used a wide range of approaches in order to define the presence of EGFr at the mRNA and protein levels in a large number of pituitary adenomas. All the techniques used demonstrated that EGFr expression is not restricted to a specific tumor type, although it is more frequent in clinically active adenomas than in NFPA. Of the 17 clinically active adenomas and the 30 NFPA examined by RT/nested PCR, 12 and 19 respectively expressed EGFr transcript. EGFr protein expression, as assessed with two different antibodies, was found in 25 of 53 clinically active pituitary adenomas. On the other hand, only 8 of 49 non-functioning adenomas displayed EGFr immunoreactivity. Similarly, EGF binding analysis revealed binding sites in all the clinically active adenomas included in the study and in only two of seven NFPA. This discrepancy in the pattern of EGFr expression at
mRNA and protein levels in NFPA can be explained by the fact that PCR is a much more sensitive technique able to document the slightest evidence of gene expression. However, immunohistochemical analysis is important since it shows whether the transcript is translated and is probably functionally available.

These data are in agreement with a previous report that has demonstrated EGFr immunoreactivity in hormonesecreting pituitary adenomas (LeRiche et al. 1996). EGFr has been shown to be present in a fraction of clinically inactive adenomas (Chaidarun et al. 1994, LeRiche et al. 1996). In our investigation this fraction is much smaller. This difference can be attributed to the much larger number of NFPA used for immunohistochemical analysis in our study. Despite the fact that EGFr expression has been reported to correlate with tumor invasiveness (LeRiche et al. 1996, Jaffrain-Rea et al. 1998), we could not find any correlation with tumor grade. This can probably be attributed to the lack of extremely aggressive cases or recurrent tumors in our study.

We also investigated the expression of the constitutive active EGFrvIII. Nested PCR on 47 pituitary adenomas 

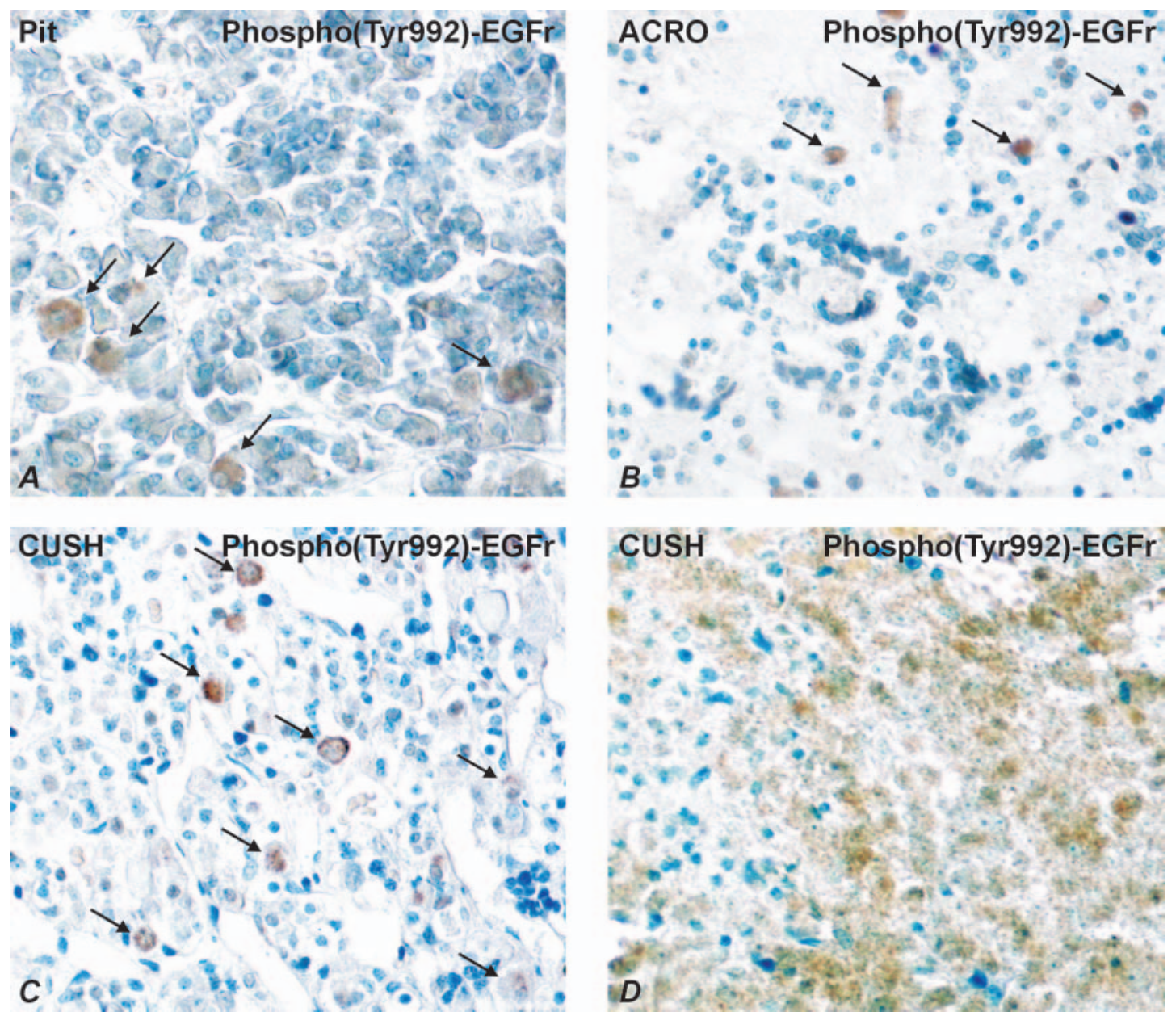

Figure 3 Phospho (Tyr992)-EGFr detection in (A) normal human anterior pituitary (Pit), (B) one ACRO (No. 2) that had $5 \%$ immunopositive cells, (C) one CUSH (No. 36) with 5\% immunopositive cells and (D) one CUSH (No. 39) with 50\% immunopositive cells. Arrows depict the individual immunopositive cells as stained with DAB (brown). All stainings were performed in paraffin-embedded sections. Nuclei are counterstained with Toluidine Blue.

failed to amplify the fragment corresponding to EGFrvIII, leading to the conclusion that EGFrvIII is unlikely to have a role in pituitary tumorigenesis.

A surprising finding of our study is that EGFr is more frequently found in CUSH, suggesting that it may be involved in their pathogenesis. The fact that EGFr is also expressed in fibroblasts prevented us from performing Western blot, which is a more quantitative approach than IHC. Nevertheless, a comparison of the percentage of EGFr immunopositive cells revealed that CUSH have significantly more EGFr expressing cells than ACRO, PROL and NFPA. This observation is in line with a previous study which reported EGFr mainly in CUSH (Kontogeorgos et al. 1996). Furthermore, EGF was shown to affect the proliferation of the mouse corticotropinoma cell line AtT-20 (van Wijk et al. 1995). CUSH are an interesting tumor entity whose etiology remains obscure (Dahia \& Grossman 1999). However, the finding of very low levels of $\mathrm{p} 27$ protein in CUSH led to the assumption that a downregulation of this cell cycle inhibitor may be an important mechanism leading to the progression of this type of pituitary adenoma (Jin et al. 1997, Lidhar et al. 1999).

p27/Kip1 is a member of the KIP family which specifically inhibits cyclin E/CDK2, as well as cyclin $\mathrm{D} / \mathrm{CDK} 4 / 6$ complexes, therefore blocking the progression from the mid-G1 to S phase of the cell cycle (Sherr 1993). Studies have shown a clear link between the components of EGFr signaling and p27/Kip1 levels, establishing $\mathrm{p} 27 / \mathrm{Kip} 1$ as an important target connecting mitogenic pathways to the cell cycle (Coats et al. 1996, Fan et al. 1997, Busse et al. 2000). In breast cancer cells, overexpression of $c$-erb2, closely related to the EGFr gene, was found to be responsible for the downregulation of p27/Kip1 (Lane et al. 2000). Having these data in mind, we sought to examine whether the presence of EGFr in 
CUSH may be responsible for the low levels of p27/Kip1 found in this type of pituitary adenoma. All CUSH that expressed EGFr had weak p27/Kip1 immunoreactivity suggesting a relationship between EGFr and p27/Kip1. However, p27/Kip1 immunoreactivity in ACRO cases expressing EGFr was still strong compared with that found in CUSH.

Since the status of the activated EGFr in normal and adenomatous pituitary has never been determined before, we sought to examine the presence of phospho-EGFr in ACRO, CUSH and NFPA. IHC was performed using two antibodies, one recognizing the phospho (Tyr992)EGFr and the other the phospho (Tyr1068)-EGFr. Phosphorylation on tyrosine 992 activates the MAP kinase (MAPK) pathway through phospholipase C- $\gamma$ (PLC $\gamma$; Emlet et al. 1997), while phosphorylated tyrosine 1068 binds to Grb2 and activates the MAPK/ERK pathway through Sos1/Ras (Rojas et al. 1996). Phospho (Tyr992)EGFr was present in all CUSH examined, but only in a few ACRO and was almost absent in NFPA. It is of interest that the few ACRO that expressed EGFr had no phospho (Tyr992)-EGFr immunoreactivity, while all the EGFr immunopositive CUSH had activated EGFr. Phospho (Tyr1068)-EGFr was absent in both normal and tumoral pituitary.

Tyrosine 992, when phosphorylated, binds directly to the SH2 domain of the PLC- $\gamma$ (Emlet et al. 1997). PLC $-\gamma$ activates protein kinase C, which triggers the MAPK/ERK pathway through Ras. Furthermore PLC- $\gamma$ facilitates the nuclear export of $\mathrm{p} 27 / \mathrm{Kip} 1$ which results in its degradation in the cytoplasm (Lee et al. 2002). It is possible that the abundance of this phospho-EGFr in CUSH is responsible for the decrease in p27/Kip1 immunoreactivity in CUSH. On the other hand, absence of phospho (Tyr992)-EGFr in most ACRO may explain why they retain $\mathrm{p} 27 / \mathrm{Kip}$ immunoreactivity despite the presence of EGFr.

In summary, this study demonstrates that EGFr expression is more common in the hormonally active pituitary adenomas than in the non-functioning ones. The finding of activated EGFr expression in CUSH indicates a role for EGF signaling in the unbalanced growth of corticotrope tumoral cells, possibly through the downregulation of p27/Kip1 protein levels. Furthermore, the strong mitogenic effect of EGFr signaling together with the fact that EGFr is expressed at high levels in a significant number of cancer types, makes EGFr a target for therapy. The antiproliferative properties of tyrphostin and other tyrosine kinase inhibitors provide a tool for the pharmacological treatment of EGFr-expressing tumors, while another line of treatment targets the EGFr itself, making use of the anti-EGFr antibody C225 (Mendelsohn 2001). Considering these, the frequent expression of EGFr in CUSH suggests that such a receptor could be a candidate therapeutic target in this type of tumor.

\section{Acknowledgements}

We acknowledge Dr C J Strasburger for the gift of mouse monoclonal GH antibody and Dr Di Stefano for the pituitary adenoma cases used for the EGF binding experiment.

\section{Funding}

This work was supported by the Deutsche Forschungsgemeinschaft ( $\mathrm{Pa} 647 / 1-1$ to $\mathrm{UP}$ ).

\section{References}

Asa SL \& Ezzat S 1998 The cytogenesis and pathogenesis of pituitary adenomas. Endocrine Reviews 19 798-827.

Birman P, Michard M, Li JY, Peillon F \& Bression D 1987 Epidermal growth factor-binding sites, present in normal human and rat pituitaries, are absent in human pituitary adenomas. Journal of Clinical Endocrinology and Metabolism 65 275-281.

Boggild MD, Jenkinson S, Pistorello M, Boscaro M, Scanarini M, McTernan P, Perrett CW, Thakker RV \& Clayton RN 1994 Molecular genetic studies of sporadic pituitary tumors. Journal of Clinical Endocrinology and Metabolism 78 387-392.

Busse D, Doughty RS, Ramsey TT, Russell WE, Price JO, Flanagan WM, Shawver LK \& Arteaga CL 2000 Reversible G(1) arrest induced by inhibition of the epidermal growth factor receptor tyrosine kinase requires up-regulation of p27(KIP1) independent of MAPK activity. Journal of Biological Chemistry 275 6987-6995.

Chabot JG, Walker P \& Pelletier G 1986 Distribution of epidermal growth factor binding sites in the adult rat anterior pituitary gland. Peptides 7 45-50.

Chaidarun SS, Eggo MC, Sheppard MC \& Stewart PM 1994 Expression of epidermal growth factor (EGF), its receptor, and related oncoprotein (erbB-2) in human pituitary tumors and response to EGF in vitro. Endocrinology 135 2012-2021.

Childs GV, Rougeau D \& Unabia G 1995 Corticotropin-releasing hormone and epidermal growth factor: mitogens for anterior pituitary corticotropes. Endocrinology 136 1595-1602.

Coats S, Flanagan WM, Nourse J \& Roberts JM 1996 Requirement of p27 Kip1 for restriction point control of the fibroblast cell cycle. Science 272 877-880.

Dahia PL \& Grossman AB 1999 The molecular pathogenesis of corticotroph tumors. Endocrine Reviews 20 136-155.

Downward J, Yarden Y, Mayes E, Scrace G, Totty N, Stockwell P, Ullrich A, Schlessinger J \& Waterfield MD 1984 Close similarity of epidermal growth factor receptor and $\mathrm{v}$-erb-B oncogene protein sequences. Nature 307 521-527.

Emlet DR, Moscatello DK, Ludlow LB \& Wong AJ 1997 Subsets of epidermal growth factor receptors during activation and endocytosis. Journal of Biological Chemistry 272 4079-4086.

Fan X \& Childs GV 1995 Epidermal growth factor and transforming growth factor-alpha messenger ribonucleic acids and their receptors in the rat anterior pituitary: localization and regulation. Endocrinology 136 2284-2293.

Fan Z, Shang BY, Lu Y, Chou JL \& Mendelsohn J 1997 Reciprocal changes in p27(Kip1) and p21(Cip1) in growth inhibition mediated by blockade or overstimulation of epidermal growth factor receptors. Clinical Cancer Research 3 1943-1948.

Jaffrain-Rea ML, Petrangeli E, Lubrano C, Minniti G, Di Stefano D, Sciarra F, Frati L, Tamburrano G, Cantore G \& Gulino A 1998 Epidermal growth factor binding sites in human pituitary macroadenomas. Journal of Endocrinology 158 425-433. 
Jaffrain-Rea ML, Ferretti E, Toniato E, Cannita K, Santoro A, Di Stefano D, Ricevuto E, Maroder M, Tamburrano G, Cantore G, Gulino A \& Martinotti S 1999 p16 (INK4a, MTS-1) gene polymorphism and methylation status in human pituitary tumours. Clinical Endocrinology 51 317-325.

Jin L, Qian X, Kulig E, Sanno N, Scheithauer BW, Kovacs K, Young WF Jr \& Lloyd RV 1997 Transforming growth factor-beta, transforming growth factor-beta receptor II, and p27 Kip1 expression in nontumorous and neoplastic human pituitaries. American Journal of Pathology 151 509-519.

Kanematsu T, Yano S, Uehara H, Bando Y \& Sone S 2003 Phosphorylation, but not overexpression, of epidermal growth factor receptor is associated with poor prognosis of non-small cell lung cancer patients. Oncology Research 13 289-298.

Klijn JG, Berns PM, Schmitz PI \& Foekens JA 1992 The clinical significance of epidermal growth factor receptor (EGF-R) in human breast cancer: a review of 5232 patients. Endocrine Reviews 13 3-17.

Kontogeorgos G, Stefaneanu L, Kovacs K \& Cheng Z 1996 Localization of epidermal growth factor (EGF) and epidermal growth factor receptor (EGFr) in human pituitary adenomas and nontumorous pituitaries: an immunocytochemical study. Endocrine Pathology 7 63-70.

Lane HA, Beuvink I, Motoyama AB, Daly JM, Neve RM \& Hynes NE 2000 ErbB2 potentiates breast tumor proliferation through modulation of $\mathrm{p} 27$ (Kip1)-Cdk2 complex formation: receptor overexpression does not determine growth dependency. Molecular Cell Biology 20 3210-3223.

Lee HT, Kim TY \& Kay EP 2002 Cdk4 and p27 Kip1 play a role in PLC-gamma1-mediated mitogenic signaling pathway of $18 \mathrm{kDa}$ FGF-2 in corneal endothelial cells. Molecular Vision 8 17-25.

LeRiche VK, Asa SL \& Ezzat S 1996 Epidermal growth factor and its receptor (EGF-R) in human pituitary adenomas: EGF-R correlates with tumor aggressiveness. Journal of Clinical Endocrinology and Metabolism 81 656-662.

Lidhar K, Korbonits M, Jordan S, Khalimova Z, Kaltsas G, Lu X, Clayton RN, Jenkins PJ, Monson JP, Besser GM, Lowe DG \& Grossman AB 1999 Low expression of the cell cycle inhibitor p27 Kip1 in normal corticotroph cells, corticotroph tumors, and malignant pituitary tumors. Journal of Clinical Endocrinology and Metabolism 84 3823-3830.

Lubrano C, Toscano V, Petrangeli E, Spera G, Trotta MC, Rombola N, Frati L, Di Silverio F \& Sciarra F 1993 Relationship between epidermal growth factor and its receptor in human benign prostatic hyperplasia. Journal of Steroid Biochemistry and Molecular Biology 46 463-468.

Mendelsohn J 2001 The epidermal growth factor receptor as a target for cancer therapy. Endocrine-Related Cancer 8 3-9.

Pagotto U, Arzberger T, Hopfner U, Sauer J, Renner U, Newton CJ, Lange M, Uhl E, Weindl A \& Stalla GK 1995 Expression and localization of endothelin-1 and endothelin receptors in human meningiomas. Evidence for a role in tumoral growth. Journal of Clinical Investigation 96 2017-2025.
Pagotto U, Arzberger T, Theodoropoulou M, Grubler Y, Pantaloni C, Saeger W, Losa M, Journot L, Stalla GK \& Spengler D 2000 The expression of the antiproliferative gene ZAC is lost or highly reduced in nonfunctioning pituitary adenomas. Cancer Research $\mathbf{6 0}$ 6794-6799.

Petrangeli E, Lubrano C, Ravenna L, Vacca A, Cardillo MR, Salvatori L, Sciarra F, Frati L \& Gulino A 1995 Gene methylation of oestrogen and epidermal growth factor receptors in neoplastic and perineoplastic breast tissues. British Journal of Cancer 72 973-975.

Ray D \& Melmed S 1997 Pituitary cytokine and growth factor expression and action. Endocrine Reviews 18 206-228.

Renner U, Pagotto U, Arzt E \& Stalla GK 1996 Autocrine and paracrine roles of polypeptide growth factors, cytokines and vasogenic substances in normal and tumorous pituitary function and growth: a review. European Journal of Endocrinology 135 515-532.

Rojas M, Yao S \& Lin YZ 1996 Controlling epidermal growth factor (EGF)-stimulated Ras activation in intact cells by a cell-permeable peptide mimicking phosphorylated EGF receptor. Journal of Biological Chemistry 271 27456-27461.

Schlegel J, Merdes A, Stumm G, Albert FK, Forsting M, Hynes N \& Kiessling M 1994 Amplification of the epidermal-growth-factorreceptor gene correlates with different growth behaviour in human glioblastoma. International Journal of Cancer 56 72-77.

Schlessinger J \& Ullrich A 1992 Growth factor signaling by receptor tyrosine kinases. Neuron 9 383-391.

Sherr CJ 1993 Mammalian G1 cyclins. Cell 73 1059-1065.

Simpson DJ, Bicknell JE, McNicol AM, Clayton RN \& Farrell WE 1999 Hypermethylation of the p16/CDKN2A/MTSI gene and loss of protein expression is associated with nonfunctional pituitary adenomas but not somatotrophinomas. Genes Chromosomes Cancer 24 328-336.

Sugawa N, Ekstrand AJ, James CD \& Collins VP 1990 Identical splicing of aberrant epidermal growth factor receptor transcripts from amplified rearranged genes in human glioblastomas. PNAS 87 8602-8606.

Tang CK, Gong XQ, Moscatello DK, Wong AJ \& Lippman ME 2000 Epidermal growth factor receptor vIII enhances tumorigenicity in human breast cancer. Cancer Research 60 3081-3087.

White BA \& Bancroft FC 1983 Epidermal growth factor and thyrotropin-releasing hormone interact synergistically with calcium to regulate prolactin mRNA levels. Journal of Biological Chemistry 258 4618-4622.

van Wijk PA, van Neck JW, Rijnberk A, Croughs RJ \& Mol JA 1995 Proliferation of the murine corticotrophic tumour cell line AtT20 is affected by hypophysiotrophic hormones, growth factors and glucocorticoids. Molecular and Cellular Endocrinology 111 13-19.

Xu YH, Richert N, Ito S, Merlino GT \& Pastan I 1984 Characterization of epidermal growth factor receptor gene expression in malignant and normal human cell lines. PNAS $\mathbf{8 1}$ 7308-7312.

Received 9 July 2004

Accepted 21 July 2004 